Nevșehir Bilim ve Teknoloji Dergisi TARGíd Özel Sayı 243-252 2016

DOI: 10.17100/nevbiltek.211003

URL: http://dx.doi.org/10.17100/nevbiltek.211003

\title{
Hıyar Yetiştiriciliğinde Selenyum ve Silisyum Yaprak Gübrelerinin Etkileri
}

\author{
Mehmet Fatih Çetinsoy ${ }^{1}$, Hayriye Yıldız Daşgan ${ }^{2 *}$ \\ ${ }^{1}$ Orman Bölge Genel Müdürlüğü, Akdeniz 33039 Mersin \\ ${ }^{2}$ Çukurova Üniversitesi, Ziraat Fakültesi, Bahçe Bitkileri Bölümü, Sarıçam 01330 Adana
}

Öz

$\mathrm{Bu}$ çalışmada, yapraktan selenyum ( $\mathrm{Se}$ ) ve silisyum ( $\mathrm{Si}$ ) gübrelemelerinin açık tarla koşullarında yetiştirilen hıyar (Cucumis sativus L.) bitkisinde büyüme, verim, bitki besin maddeleri alımı ve bazı meyve kalite özellikleri üzerine etkileri incelenmiştir. Selenyum, $\mathrm{Na}_{2} \mathrm{SeO}_{4}$ bileşiği olarak 50 ppm dozunda ve Silisyum, $\mathrm{K}_{2} \mathrm{SiO}_{3}$ bileşiği olarak 300 ppm dozunda yapraklardan sprey şeklinde olmak üzere 3 defa 15 gün aralıklarla uygulanmıştır. Deneme süresince bitkilerde ve meyvelerde ölçülen, analiz edilen ve incelenen parametreler olarak; yaprak sayısı, bitki boyu, hasat süresince meyve sayısı ve ağırlığı, meyve çapı, meyve boyu, meyve sertliği, meyvede suda çözülebilir kuru madde (SÇKM), meyvede $\mathrm{pH}$, meyvede EC, yaprakta N, P, K, Mg, Ca, Fe, Se ve Si içerikleri belirlenmiştir. Ayrıca Se ve Si'un insan beslenmesi üzerine olumlu etkileri nedeniyle, yaprak gübrelemesi ile meyvenin Se ve $\mathrm{Si}$ içeriğinin değişimini incelemek için meyvede Se ve Si analizleri yapılmıştır. Sonuç olarak, yapraktan Se uygulaması hıyar meyve veriminde \% 11, Si, \% 8 ve Se + Si uygulaması ise verimde \% 25 artışlar sağlamıştır. Bitki büyümesi ve meyve özellikleri üzerine Se ve Si’un etkileri belirgin değilken, meyvenin Se ve Si içeriği üzerine artırıcı etkiler görülmüştür. Silisyum uygulamasında dikkat çekici bir şekilde kontrole göre \%134 daha sert meyve eti olmuştur. Selenyum tek başına ve Se + Si uygulamalarında ise kontrole göre sirasıly \% 35 ve $\% 38$ daha sert meyveler oluşmuştur.

Anahtar Kelimeler: Yaprak gübrelemesi, Se, Si, Cucumis sativus

\section{The Effects of Foliar Spraying of Selenium and Silicon on Cucumber Plants}

\begin{abstract}
In the present study, foliar applications of selenium (Se) and silicon (Si) on the open field grown cucumber (Cucumis sativus L.) were studied. Treatments were performed by four ways; 1) Selenium, 2) Silicon, 3) Control, 4) Se + Si together. The effects of Se and Si on plant growth, yield, fruit properties, leaf mineral concentrations and fruit Se, Si contents have been investigated. The concentration of $50 \mathrm{ppm}$ Se from $\mathrm{Na}_{2} \mathrm{SeO}_{4}$ and $300 \mathrm{ppm} \mathrm{Si}$ from $\mathrm{K}_{2} \mathrm{SiO}_{3}$ were applied to the leaves three times by 15 days interval during the growing period. In order to investigate the effects of the Se and $\mathrm{Si}$ on plant growth and fruit properties following parameters were investigated: plant height, leaf number, fruit weight, fruit diameter, fruit length, $\mathrm{pH}$, and EC and total soluble solids of fruit juice. The fruit harvests were performed every 2-3 days and total yield was collected. The effects of the Se and Si on the leaf concentrations of N, P, K, Ca, Mg, Se and Si were investigated. Fruit Se and Si contents were also analyzed. As results, the effects of foliar applications of Se and Si on total yield were significant and increasingly affected the yield. Selenium, Si and Se+Si have increased the yield by $11 \%, 8 \%$ and $25 \%$, respectively. The most remarkable effect on yield was together using of Se+Si. Fruit Se and Si contents also increased by the foliar applications. The increasing of fruit firmness was $134 \%$ in Si foliar application alone, Se and Se+Si together have also increased the fruit firmness by $35 \%$ and $38 \%$, respectively.
\end{abstract}

Keywords: Foliar fertilization, Se, Si , Cucumis sativus

*e-mail : dasgan@cu.edu.tr 


\section{Giriş}

Bitkiler yaşamsal faaliyetlerini sürdürebilmeleri, büyüyüp gelişebilmeleri ve ürün verebilmeleri için yetiştikleri ortamından birçok besin elementi alırlar. Bunların sayısı 74 kadardır. Ancak bu elementlerin bir kısmı (20 kadar) bitkiler için mutlak gerekli olan besin elementidir [1]. Yaprak gübrelemesi, bitki besin maddelerinin bitkinin üst aksamına ve özellikle yapraklara püskürtülerek uygulanmasıdır. Bitkilerde bazı hallerde, besin elementi noksanlıklarının kısa sürede giderilmesi amacı ile ya da topraktan bitkinin beslenmesine takviye amaciyla yapraktan gübreleme yapılmaktadır. Fizyolojik bakımdan mikro elementlerin önemi, makro elementlerden daha az değildir. Çünkü tüm diğer besin elementlerinin yeter miktarda bulunmasına rağmen, tek bir mikro besin elementinin noksanlığı bile bitkinin gelişmesinin durmasına ve bitkinin verimlilik düşüşüne sebep olabilmektedir [1].

Selenyum, insan ve hayvan beslenmesi için önemli bir mikro besin elementidir. Yüksek dozda alındığında insanlar ve hayvanlar için toksik etki yapabilir. Selenyum antioksidatif etkilerinden dolayı bitki büyüme ve gelişmesine, ürün kalitesine faydalı katkılar sağlamaktadır [2]. Bitkilerdeki Se miktarı \% 2.5'dan azdır (kuru ağırlık) [2]. Bitkiler, insan gıdası zincirinde Se transferinde çok önemli rol oynamaktadır [3, 4, 5]. Tahıllar, kırmızı et ve balık en önemli Se kaynaklarıdır [4].

Silisyum birçok doğal bileşiğin yapısına giren bir maddedir ve Si bileşikleri arasında en önemlileri silis ve silikatlardır [6]. Bitki biyolojisinde Si'un rolü şu ana kadar az anlaşılmıştır. Silisyum, yüksek bitkilerin gelişimi için gerekli mutlak elementler arasında yer almayan, ancak yararlı olduğu belirlenen bir bitki besin elementi olarak kabul edilmektedir [7, 8]. Silisyumun bitki gelişiminde temel element olup olmadığını saptamak için birçok önemli çalışma yürütülmüştür [9, 10, 11, 12]. Bitkilerle ilgili yapılan abiyotik stres çalışmalarında silisyumun, tuz stresi [13] ve kuraklığa [14] karşı bitki direncini/toleransını arttırdığı belirtilmiştir.

Çoğu bitkilerde Si konsantrasyonu, fosfor (P), kükürt (S), kalsiyum (Ca) ve magnezyum (Mg) ile benzer miktarlardadır ve bazen azot $(\mathrm{N})$ ve potasyum $(\mathrm{K})$ konsantrasyonu kadar yüksek olabilir [15]. Silisyum bitki gelişimi için gereken makro elementler kadar yüksek konsantrasyonlarda biriktirilebilir. Silisyum, bir besin elementi olarak rol alabilmekte ve bitkide gelişmeyi artırıcı etkide bulunmaktadır. Yeterince silisyum alan bitkilerin su kaybının azaldığı; silisyum birikmesinin mantar hastalıklarına ve böcek zararlarına karşı dayanıklılı̆̆ biriktirildiği zaman bitkiye zarar vermeyen tek elementtir [16]. Silisyum, insan vücudunun normal gelişimi ve beslenmesi için gerekli olan 25 element arasında yer almaktadır ve en çok bulunan üçüncü elementtir [17].

Burada sunulan çalışmanın amacı, Bu çalışmanın amacı, Adana ekolojik koşullarında, açıkta ilkbahar-yaz sezonunda açık saha hıyar yetiştiriciliği takvimine uygun bir şekilde yapraktan $\mathrm{Se}$ ve $\mathrm{Si}$ uygulaması ile yetiştirilen hıyar bitkilerinde büyüme ve gelişme parametreleri, toplam ürün verimi ve hıyar meyve kalite özellikleri ile bitki besin elementleri konsantrasyonunun belirlenmesidir. Hıyar seçilmesinin nedeni ise bu türün büyüme ve verimlilik tepkilerinin çok hızlı olarak alınabilmesidir.

\section{Materyal ve Metot \\ 2.1. Materyal}

Deneme Çukurova Üniversitesi Ziraat Fakültesi Bahçe Bitkileri Bölümü’ne ait deneme alanında açık arazide yürütülmüştür. Hıyar çeşidi olarak, açık yetiştiricilik koşullarına uygun Toros $F_{1}$ hıyar çeşidi 
kullanılmıştır. Selenyum kaynağı olarak $\mathrm{Na}_{2} \mathrm{SeO}_{4} 50$ ppm, Silisyum kaynağı olarak $\mathrm{K}_{2} \mathrm{SiO}_{3} 300$ ppm dozlarında kullanılmıştır. Deneme alanının toprak analiz sonuçları Tablo 1'de sunulmaktadır.

Tablo 1. Deneme alanına ait toprak analiz sonuçları

\begin{tabular}{|c|c|c|c|c|}
\hline \multicolumn{2}{|c|}{ Toprak Özellikleri } & & Analiz Sonucu (0-30 cm) & Değerlendirme \\
\hline $\mathrm{pH}$ & -- & $1: 2.5$ & 8.4 & Kuvvetli Alkali \\
\hline Kireç & $(\%)$ & Kalsimetrik & 18.1 & Fazla Kireçli \\
\hline Tuz & $(\%)$ & $1: 2.5$ & 0.013 & Tuzsuz \\
\hline Doygunluk & $(\%)$ & Saturasyon & 65 & Bünye: Killi Tın \\
\hline Org. Mad. & $(\%)$ & Walkey Black & 0.6 & Çok Az \\
\hline Toplam N & $(\%)$ & Kjeldahl & 0.082 & $\mathrm{Az}$ \\
\hline Alınabilir P & $\left(\mathrm{kg} \mathrm{P}_{2} \mathrm{O}_{5} / \mathrm{da}\right)$ & Olsen-Spekt. & 6.3 & $\mathrm{Az}$ \\
\hline Alınabilir K & $\left(\mathrm{kg} \mathrm{K}_{2} \mathrm{O} / \mathrm{da}\right)$ & A.Asetat-ICP & 112.3 & Fazla \\
\hline Alınabilir $\mathrm{Ca}$ & (kg CaO/da) & A.Asetat-ICP & 1990.1 & Fazla \\
\hline Alınabilir Mg & (kg MgO/da) & A.Asetat-ICP & 240.3 & Fazla \\
\hline Alınabilir Fe & (ppm) & DTPA-ICP & 0.85 & $\mathrm{Az}$ \\
\hline Alınabilir Mn & (ppm) & DTPA-ICP & 0.82 & $\mathrm{Az}$ \\
\hline Alınabilir Zn & (ppm) & DTPA-ICP & 0.11 & $\mathrm{Az}$ \\
\hline Alınabilir $\mathrm{Cu}$ & (ppm) & DTPA-ICP & 0.26 & $\mathrm{Az}$ \\
\hline
\end{tabular}

\subsection{Metot}

Deneme "Tesadüf Blokları Deneme Planına" göre 4 uygulamalı ve 4 tekerrürlü olarak planlanmıştır. Her tekerrürde 16 bitki kullanılmış ve toplam 256 adet hıyar fidesi kullanılmıştır. Sıra üzeri $50 \mathrm{~cm}$ ve sıra arası makineli işlemeye uygun olarak $150 \mathrm{~cm}$ olacak şekilde 1111 bitki da $^{-1}$ bitki yoğunluğu ile dikim yapılmıştır. 15.03.2013 tarihinde hıyar tohumları cam örtülü fidelik serasında 2:1 torf ve perlit karışımı olan viyollere ekilmiştir. Dikim büyüklüğüne gelen fideler 05.04.2013 tarihinde açık araziye dikilmiştir. Toprak analiz sonuçları da dikkate alınarak, toplamda dekara verilen saf madde miktarı $24 \mathrm{~kg}$ $\mathrm{N}, 10 \mathrm{~kg} \mathrm{P}_{2} \mathrm{O}_{7}, 41 \mathrm{~kg} \mathrm{~K} \mathrm{~K}_{2} \mathrm{O}, 15 \mathrm{~kg} \mathrm{MgO}$ olmuştur. Bu çalışmanın hedefi olarak hıyar bitkisi yapraklarına aşağıda gösterilen 4 farklı uygulama yapılmıştır:

A- Kontrol parsellerine sadece su püskürtülmüştür,

B- Selenyum $50 \mathrm{ppm}$ dozunda sodyum selenat $\left(\mathrm{Na}_{2} \mathrm{SeO} 4\right)$ olarak,

C- Silisyum $300 \mathrm{ppm}$ dozunda potasyum silikat $\left(\mathrm{K}_{2} \mathrm{SiO}\right)$ olarak,

D- 50 ppm Se ve 300 ppm Si beraber $\mathrm{Na}_{2} \mathrm{SeO} 4$ ve $\mathrm{K}_{2} \mathrm{SiO} 3$ olarak.

Silisyum $\left(\mathrm{K}_{2} \mathrm{SiO}_{3}\right)$ uygulamasından gelebilecek $\mathrm{K}$ elementini dikkate almak için, potasyum sülfat $\left(\mathrm{K}_{2} \mathrm{SO}_{4}\right)$ bileşiği, Se verilen ve kontrol bitkilerine yapraktan aynı tarihlerde uygulanmıştır. Yaprak gübresi uygulamaları 08.05.2013, 22.05.2013 ve 05.06.2013 tarihlerinde olmak üzere 3 defa, 15 gün aralıklarla yapılmıştır (Şekil 1). Selenyum ve Si son konsantratonları yukarıdaki gibi olmak üzere, hazırlanan yaprak gübresi miktarları yaprakların tamamı homojen sslanacak şekilde, sırt pompası ile 15 litre başlanmış ve bitkiler büyüdükçe artırılarak vegetasyon sonunda 200 litreye kadar artırılmıştır. 


\subsection{Yapılan Ölçüm ve Analizler}

Uygulamaların bitki büyümesi üzerine etkilerini görmek için 3 farklı tarihte 15 Mayıs, 29 Mayıs ve 12 Haziran olmak üzere bitki boyu ve yaprak sayısı ölçülmüş ve her ölçüm sonrası element analizleri için yaprak örnekleri alınmıştır. İlk meyve hasadı 15 Mayıs 2013 tarihinde olmak üzere toplam 7 hasat yapılmıştır. Meyve pomolojik analizleri için 27.05.2013 tarihinde yapılan hasatta her tekerrürden 10 adet meyve alınarak, ortalama meyve ağırlığı $(\mathrm{g})$, meyve boyu $(\mathrm{cm})$, meyve çapı $(\mathrm{mm})$, meyve eti sertliği $(\mathrm{kg})$, meyve suyunda $\mathrm{pH}$, meyve suyunda EC (mS/cm), meyve suyunda S.Ç.K.M. (\%) incelenmiş ve değerler kaydedilmiş̧ir. Meyve Ağırlığı 0,1 g hassasiyetindeki bir terazide teker teker tartılmıştır. Meyve boyları 1 mm hassasiyetindeki bir cetvel ile ölçülmüştür. Meyve çapı ölçümlerinde $0.01 \mathrm{~mm}$ hassasiyetindeki bir kompas kullanılarak ölçülmüştür. Meyvede Suda çözünebilir Kuru Madde Miktarı (SÇKM) için katı meyve suyu sıkacağında meyve suyu çıkarılmıştır. Çıkartılan meyve suyu bir refraktometre ile okunmuş \% olarak SÇKM si belirlenmiş̧ir. Meyve Suyu pH'sı, meyve suyundan $\mathrm{pH}$ metre yardımıyla meyve suyu pH sı ölçülmüştür. Meyve Suyu EC'si, meyve suyundan EC metre yardımıyla meyve suyu EC'si ölçülmüştür.

Hıyar bitkilerinde 29 Mayıs-12 Haziran tarihleri arasında alınan yaprak örneklerinde N, P, K, Ca, $\mathrm{Mg}$, Se ve Si analizleri yapılmıştır. Ayrıca meyve dokularında Se ve Si analizleri yapılmıştır. Yaprak ve meyve örnekleri kontaminasyona karş1 \%0.1 lik deterjan ile yıkanarak durulandıktan sonra 3 kez saf su ile yıkanıp etüvde $65^{\circ} \mathrm{C}$ 'de sabit ağırlığa ulaşıncaya kadar kurutulmuştur ve öğütülmüştür. Öğütülmüş örneklerden $\mathrm{P}, \mathrm{K}, \mathrm{Ca}, \mathrm{Mg}$, Se analizleri için $200 \mathrm{mg}$ tartılmış ve $550^{\circ} \mathrm{C}^{\prime}$ de 8 saat süreyle yakılmıştır. Oluşan kül \% 3.3'lük HCI asitte çözülerek filtre edilmiştir ve elde edilen süzük atomik absorbsiyon spektrometrede $\mathrm{K}, \mathrm{Ca}, \mathrm{Mg}$ okumaları emisyon modunda Se okumaları ise absorbans modunda yapılmışıtır [18]. Fosfor analizleri Barton yöntemine göre Azot (N) analizleri Kjeldahl yöntemi ile belirlenmiştir [19].

Silisyum analzileri farklı bir teknik kullanılarak gerçekleştirilmiştir. Bu amaçla öğütülmüş örneklerden $450 \mathrm{mg}$ tartılmış ve $15 \mathrm{ml}$ Hidroflorik asit (HF) + Hidroklorik asit (HCl) karışımı (v:v) çözelti eklenmiştir. Daha sonra örnekler çalkalayıcıda 150 devirde 2 saat çalkalanarak çeker ocak altında süzük alınmıştır. Elde edilen süzükler Atomik Absorbsiyon Spaktrometrede absorbans modunda Azot Protoksit + Asetilen gazı kullanılarak Si okumaları yapılmıştır. Bu analizde kullanılan Hidroflorik (HF) asitin camı aşındırıcı özelliği nedeniyle kullanan malzemeler polietilen (plastik) malzeme olması gerekmektedir [20].

\subsection{Verilerin Değerlendirilmesi}

Denemede elde edilen veriler JUMP paket programına tabi tutularak istatistiksel analizleri yapılmış, ortalamalar LSD testine göre karşılaştırılmıştır. 


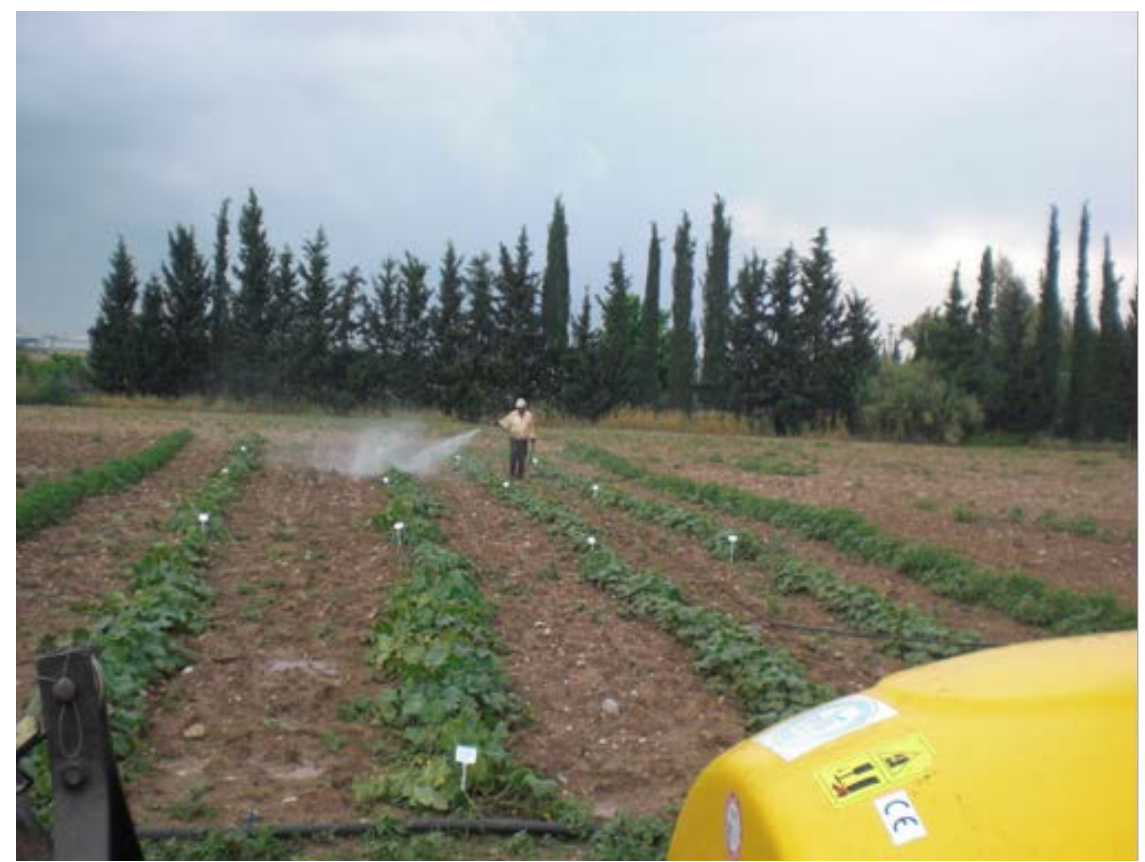

Şekil 1. Deneme alanında hıyar bitkilerine yaprak uygulamaları yapılırken bir görüntü

\section{Bulgular ve Tartışma}

\subsection{Uygulamaların Bitki Büyümesi Üzerine Etkileri}

Hıyar bitkileri yapraklarına uygulanan Se ve Si elementlerinin bitki büyümesi üzerine etkilerini görmek için farklı dönemlerde ölçülen bitki boy ve yaprak sayısı değeri Tablo 2 ve 3'de sunulmaktadır. Uygulamaların bitki boyu ve yaprak sayısına artırıcı etki yapmadığı görülmektedir. 12 Haziran tarihli son dönem ölçümlerinde kontrol parsellerine göre $\mathrm{Se}$ ve $\mathrm{Si}$ uygulamalarında belirgin bir azalma görülmektedir. Bunun olası nedeni, üçüncü dönemde, 15 Mayıs tarihinde başlayan meyve hasatları ile beraber bitki generatif gelişmeye yönlendiğinden gücünü bu tarafa aktardığı için bitkide vegetatif gelişmenin azaldığı düşünülebilir. Çünkü 3. dönem ölçümleri sırasında hıyar meyve verimleri, uygulama parsellerinde kontrole göre daha yüksek olmuştur (Tablo 2, 3). Domateste tuz stresi üzerine selenyum ve silisyum etkilerinin incelendiği bir çalışmada [21], Se uygulaması tuzsuz koşullarda en yüksek bitki boyu ve yaprak sayısını verirken, Si uygulaması tuzlu koşullarda en düşük bitki boyu ve yaprak sayısı sonucu vermiştir. Soya fasulyesi tohumlarına ekim öncesi 5 ppm Se ve ekimden 45, 60, 75 gün sonra yapraktan 50 ppm ve 100 ppm Se uygulandığında [22], bitki boyu, kök uzunluğu ve yaprak sayısının başta olmak üzere bitki gelişiminin arttığı rapor edilmiştir.

Tablo 2. Denemede yapraktan selenyum ve silisyum uygulamasının hıyar bitkilerinde bitki boyu üzerine etkileri (cm)

\begin{tabular}{llcc}
\hline Uygulama & $\begin{array}{l}\text { 1.Ölçüm } \\
(15 \text { Mayıs })\end{array}$ & $\begin{array}{c}\text { 2.Ölçüm } \\
\text { (29 Mayıs) }\end{array}$ & $\begin{array}{c}\text { 3.Ölçüm } \\
(12 \text { Haziran })\end{array}$ \\
\hline Selenyum & 69.33 & 97.26 & 114.97 ab \\
Silisyum & 66.30 & 89.11 & 117.65 ab \\
Kontrol & 72.35 & 97.55 & 123.98 a \\
Selenyum +Silisyum & 70.58 & 94.83 & 107.33 b \\
\hline
\end{tabular}

Tablo 3. Denemede yapraktan selenyum ve silisyum uygulamasının hıyar bitkilerinde yaprak sayısı üzerine etkileri (adet/bitki)

\begin{tabular}{|c|c|c|c|}
\hline Uygulama & $\begin{array}{l}\text { 1.Ölçüm } \\
\text { (15 Mayıs) }\end{array}$ & $\begin{array}{l}\text { 2.Ölçüm } \\
\text { (29 Mayı) }\end{array}$ & $\begin{array}{l}\text { 3.Ölçüm } \\
\text { (12 Haziran) }\end{array}$ \\
\hline Selenyum & $14.85 \quad \mathrm{a}$ & 18.14 & $20.13 \quad b$ \\
\hline Silisyum & $12.73 \quad b$ & 17.13 & 22.48 \\
\hline Kontrol & $13.56 \mathrm{ab}$ & 18.90 & 24.33 \\
\hline Selenyum +Silisyum & $13.20 \mathrm{ab}$ & 18.28 & 20.41 \\
\hline
\end{tabular}




\subsection{Toplam Meyve Verimi}

Deneme süresince $7 \mathrm{kez}$ yapılan hasatlar sonrasında toplam verim elde edilmiştir. Farklı uygulamalara göre hıyar verim değerleri kg/da ve g/bitki olarak Tablo 4'de ifade edilmiştir. Meyve sayıları da aynı tablo’da adet/m ve adet/bitki olarak gösterilmektedir. Hıyar toplam verimi üzerine farklı yaprak uygulamalarının etkileri önemli olmuştur. Selenyum uygulaması kontrol bitkilerine göre \%11, Silisyum uygulaması \%8 ve Se $+\mathrm{Si}$ uygulaması ise kontrol bitkilerine göre verimde \%25 artışlar sağlamıştır. Her iki mineralin beraberce yapraktan kullanımı verimi artırıcı etki yapmıştır Meyve sayılarına bakıldığında uygulamalarda kontrole göre artışların daha düşük olduğu görülmektedir Buna göre meyve sayısı kontrole göre sırasıyla $\mathrm{Se}$, Si ve Se+Si uygulamalarında \%0.4, \%9 ve \%1.2 artışlar sağlamıştır (Tablo 4). Soya fasulyesi tohumlarına ekim öncesi 5 ppm Se ve ekimden 45, 60, 75 gün sonra yapraktan 50 ppm ve 100 ppm Se uygulandığında yapraklarda kuru madde birikiminin, soya veriminin, soyada protein içeriğinin arttığı bildirilmektedir [22]. Yem bitkisi olarak yonca yetiştiriciliğinde yapraktan 50, 100 ve 200 ppm Se uygulanan bir çalışmada, yonca verimi ve kalitesinin arttığını bildirilmiştir [23]. Hayvan ve dolaylı olarak insan beslenmesi bakımından yoncalarda Se içeriği artarken, Ca ve P da arttığı ayrıca yoncada yaprak Se uygulaması ile yağ içeriğinin artığı proteinin aynı kaldığ Si çözeltisini 3 defa uygulanan bir diğer çalışmada, bitkilerde fotosentezin, büyümenin arttı̆̆ı ayrıca fidanların yüksek sıcaklık ve kuraklık streslerine karşı dayanımlarının arttığı bildirilmektedir [24].

Tablo 4. Deneme boyunca hasat edilen hıyar meyvelerinde toplam verim ve meyve sayısı değerleri

\begin{tabular}{lcccc}
\hline Uygulama & $(\mathrm{kg} / \mathrm{da})$ & $(\mathrm{g} / \mathrm{bitki})$ & $\left(\mathrm{adet} / \mathrm{m}^{2}\right)$ & $($ adet/bitki) \\
\hline Selenyum & $1156 \mathrm{~b}$ & $1041 \mathrm{~b}$ & 10.91 & 9.82 \\
Silisyum & $1123 \mathrm{~b}$ & $1011 \mathrm{~b}$ & 11.82 & 10.64 \\
Kontrol & $1044 \mathrm{~b}$ & $939 \mathrm{~b}$ & 10.87 & 9.79 \\
Se+Si & $1309 \mathrm{a}$ & $1178 \mathrm{a}$ & 11.00 & 9.90 \\
\hline
\end{tabular}

\subsection{Uygulamaların Meyve Kalitesi Üzerine Etkileri}

Uygulamaların meyvede bazı fiziksel ve kimyasal özelliklere olan etkileri Tablo 5 ve 6'da verilmiştir. Meyve ortalama ağırlığı bakımından her ne kadar uygulamalar arasındaki fark istatistiksel olarak önemli bulunmasa da Se ve özellikle Se + Si beraber kullanıldığında irilik üzerine hafif bir artırıcı etki olmuştur. Uygulamaların meyve çapı ve boyu değerleri üzerine etkileri benzer bulunurken, meyve sertliği Si uygulamasında dikkat çekici bir şekilde kontrole göre \%134 yüksek olmuştur. Selenyum tek başına ve Se $+\mathrm{Si}$ uygulamalarında ise kontrole göre sırasıyla \% 35 ve \%38 daha sert meyveler oluşmuştur. Hıyar gibi çabuk bozulan bir sebzede sert meyve eti raf ömrünü uzatan bir özelliktir (Tablo 5). Meyvelerin suyu çıkarılarak pH, EC ve suda çözülebilir kuru madde (SÇKM) bakımından analiz yapıldığında, yaprak uygulamalarının incelenen meyve kimyasal özellikleri üzerine etkilerinin olmadığı görülmüştür (Tablo 6).

Tablo 5. Selenyum ve Si yaprak uygulamalarının hıyar meyvelerinde bazı fiziksel özellikler üzerine etkileri

\begin{tabular}{|c|c|c|c|c|}
\hline Uygulama & $\begin{array}{l}\text { Meyve } \\
\text { Ağırlığı (g) }\end{array}$ & $\begin{array}{l}\text { Meyve } \\
\text { Çap1 (mm) }\end{array}$ & $\begin{array}{l}\text { Meyve } \\
\text { boyu }(\mathrm{cm})\end{array}$ & $\begin{array}{l}\text { Meyve eti sertliği } \\
(\mathrm{kg})\end{array}$ \\
\hline Silisyum & 95.08 & 36.79 & 13.63 & 8.12 a \\
\hline Kontrol & 96.01 & 38.66 & 14.50 & 3.82 c \\
\hline Selenyum+Silisyum & 118.75 & 36.18 & 14.33 & $5.29 \mathrm{~b}$ \\
\hline
\end{tabular}


Tablo 6. Selenyum ve Si yaprak uygulamalarının hıyar meyvelerinde bazı kimyasal özellikler üzerine etkileri

\begin{tabular}{lccc}
\hline Uygulama & Meyve $\mathrm{pH}$ & Meyve EC & Meyve SÇKM \\
\hline Selenyum & 5.73 & 4.80 & 3.70 \\
Silisyum & 5.80 & 4.66 & 3.80 \\
Kontrol & 5.66 & 4.89 & 3.58 \\
Selenyum+Silisyum & 5.70 & 4.70 & 3.58 \\
\hline
\end{tabular}

\subsection{Hiyar Yapraklarında Besin Elementleri Konsantrasyonları}

Yapraktaki N, P, K, Ca ve Mg elementleri konsantrasyonları bakımından uygulamaların önemli bir fark yaratıcı bir etkisi olmamıştır (Tablo 7). Hıyar yapraklarında, yeterli beslenme durumunda $\mathrm{N}$ konsantrasyonu \% 4.0-6.0 arasında ve $\mathrm{P}$ ise \% 0.25-1.25 arasında olduğu bildirilmektedir [19]. $\mathrm{Bu}$ denemedeki hıyar yapraklarında N ve P konsantrasyonları, yeterli beslenme referans değerleri içinde kalmaktadır. Potasyum konsantrasyonu bakımından, yeterli beslenme aralığı K \% 3.50-5.00 arasında [19] ve bir diğer kaynakta ise \% 2.5-5.40 arasında [25] olduğu bildirilmektedir. Burada sunulan çalışmada yaprak K değerleri sunulan referans aralıklar içerisinde çoğunlukla kalmış, sadece Se uygulamasında \%2.5'in altına düşmüştür. Deneme alanı toprağında K fazla olmasına (Tablo 1) ve yetiştiricilik sırasında K'lu gübre kullanılmasına rağmen yaprak K değerleri düşük çıkabilmiştir. Ancak bitki yaprak ve meyvelerde $\mathrm{K}$ eksiklik semptomları görülmemiştir. Hıyar yapraklarında, yeterli $\mathrm{Mg}$ konsantrasyonu \% 0.30-1.20 arasında olduğu bildirilmektedir [19]. Bu denemede $\mathrm{Mg}$ değerleri bu referans aralık içerisinde kalmış ve bitkiler Mg bakımından yeterli beslenmiştir. Hıyar yapraklarında yeterli Ca, \% 1.50-4.00 arasında olduğu bildirilmektedir [19]. Denemede Ca değerleri bu aralık içerisinde olmuştur.

Tablo 7. Selenyum ve Si yaprak uygulamalarının hıyar bitkisi yapraklarında makro besin elementleri üzerine etkileri (\%)

\begin{tabular}{lccccc}
\hline Uygulama & Azot & Fosfor & Potasyum & Magnezyum & Kalsiyum \\
\hline Selenyum & 6.56 & 0.59 & $2.44 \mathrm{~b}$ & 0.518 & 3.58 \\
Silisyum & 6.41 & 0.54 & $2.62 \mathrm{ab}$ & 0.543 & 3.51 \\
Kontrol & 6.38 & 0.54 & $2.74 \mathrm{a}$ & 0.558 & 3.88 \\
Selenyum+Silisyum & 6.33 & 0.61 & $2.68 \mathrm{ab}$ & 0.540 & 3.78 \\
\hline
\end{tabular}

$\mathrm{Bu}$ denemede hiyar bitkilerine yapraktan 3 defa uygulanan 300ppm Si dozu yapraklarda Si konsantrasyonunu istatistiki olarak önemli seviyede artırmamıştır (Tablo 8). Hiç uygulama yapılmayan kontrol bitkileri yapraklarında bile Si belirlenmiştir. Hiyar bitkilerinin toprakta bulunan silisyumu aldıkları analiz sonuçlarında görülebilmektedir. Gelecek çalışmalarda uygulama sayısı artırılması ve Si dozu yükseltilmesi düşünülebilir. Bitkiler Si içerikleri bakımından Si almayanlar ve Si biriktirenler olarak iki önemli gruba ayrılmaktadır [26]. Silisyum almayanlarda Si dozu \%0.5'in altında olmaktadır. Biriktirici olanlarda ise iki grup söz konusu olmaktadır: a) \%0.5 - 2.0 arasında olanlar ve b) \%2.0 - 4.0 arasında olanlar [26]. Ayrıca çeltik bitkisi özel biriktirici bir tür olarak \%4’ün üzerinde Si bulundurabilmektedir [26]. Çift çenekli bitkilerin çoğu Si almayanlar grubunda olmasına karşın sadece 
hıyar burada istisnadır. Hıyarda Si konsantrayonu \%1-2 seviyesine kadar çıkabilmektedir [26]. Buna göre, gelecek çalışmalarda hıyara özel Si dozu 300 ppm üzerine çıkılabilir ve uygulama sayısı artırılabilir.

Hıyar meyve örneklerinde yapılan selenyum analizlerinde en yüksek Se içeriği, sadece Se ve Se+Si beraber uygulanan bitkilerin meyvelerinde bulunmuştur (Tablo 9). Diğer uygulamalarda meyvede selenyum içeriği beklendiği gibi birbirine yakın ve daha düşük bulunmuştur (Tablo 9). Bu sonuç ile $\mathrm{Se}+\mathrm{Si}$ uygulamasının yapraklardan beraber yapılması verim de olduğu gibi meyvede içeriğinde de Se’ mu artırmıştır. Hıyar meyve örneklerinde yapılan silisyum analizinde ise en yüksek silisyum değeri silisyum uygulanan bitkilerde bulunmuştur. Bunu sırasıyla Se ve Se+Si uygulaması yapılan bitkiler izlemiştir. Hıyar meyvelerinde en düşük silisyum değeri kontrol uygulamasında bulunmuştur (Tablo 9).

Tablo 8. Selenyum ve Si yaprak uygulamalarının hıyar bitkisi yapraklarında Se ve Si elementleri içeriği üzerine etkileri

\begin{tabular}{lcc}
\hline Uygulama & Selenyum (ppm) & Silisyum (\%) \\
\hline Selenyum & 645.00 a & 0.45 \\
Silisyum & 595.00 ab & 0.56 \\
Kontrol & 525.00 b & 0.51 \\
Selenyum+Silisyum & 672.50 a & 0.48 \\
\hline
\end{tabular}

Tablo 9. Hıyar bitkilerine yapraktan Se ve Si uygulandığında meyvelerde Se ve Si içeriği üzerine etkileri

\begin{tabular}{lcc}
\multicolumn{1}{c}{ Tablo 9. Hiyar bitkilerine yapraktan Se ve Si uygulandiğında meyvelerde Se ve Si içeriği üzerine etkileri } & Meyvede Si (\%) \\
\hline Uygulama & Meyvede Se (ppm) & $0.170 \mathrm{ab}$ \\
Silisyum & $300.00 \mathrm{~b}$ & $0.189 \mathrm{a}$ \\
Kontrol & $283.33 \mathrm{~b}$ & $0.120 \mathrm{~b}$ \\
Selenyum +Silisyum & $293.33 \mathrm{~b}$ & $0.159 \mathrm{ab}$ \\
\hline
\end{tabular}

\section{Sonuç}

Hıyar yetiştiriciliğinde Selenyum 50 ppm dozunda $\mathrm{Na}_{2} \mathrm{SeO}_{4}$ olarak ve Silisyum 300 ppm dozunda $\mathrm{K}_{2} \mathrm{SiO}_{3}$ olarak yapraktan 15 gün aralıklarla üç defa uygulandığında, selenyumun tek başına uygulaması kontrol bitkilerine göre \%11, Silisyum tek uygulaması $\% 8$ ve $\mathrm{Se}+\mathrm{Si}$ beraber uygulaması ise kontrol bitkilerine göre verimde \%25 artışlar sağlamıştır. Her iki mineralin beraberce yapraktan kullanımı verimi artırıcı etki yapmıştır. Hıyar üreticilerine bu iki elementin yaprak gübresi olarak kullanılması önerilebilir, hatta tek tek kullanılması yanında beraber önerilmesi daha etkin olabilir.

Hiyar gibi çabuk bozulan bir meyvede Se ve özellikle Si uygulamaların meyve etinde sertlik artırıcı etkileri oldukça önemlidir. Silisyum uygulamasında dikkat çekici bir şekilde kontrole göre \%134 daha sert meyve eti olmuştur. Selenyum tek başına ve Se $+\mathrm{Si}$ uygulamalarında ise kontrole göre sırasıyla \% 35 ve \%38 daha sert meyveler oluşmuştur. Meyvede Se ve Si içeriklerine bakıldığında, Se+Si uygulamasının beraber yapılması verim de olduğu gibi meyvede de Se içeriğini artırmıştır. Meyvede en yüksek Si içeriği, tek başına silisyum uygulanan bitkilerde bulunmuştur. Meyvede bu elementlerin artması insan beslenmesi bakımından bir katma değer sağlamıştır ve meyve kalitesini artırıcı bir etki yapmiştır.

Sonuç olarak, Se ve Si elementlerinin hıyar yetiştiriciliğinde yaprak uygulaması şeklinde yapılması, bitki büyümesinde fark edilir bir artış sağlamamış ancak meyve verimi artırıcı etki yapmıştır. Bitkilerin diğer elementlerce beslenmesinde eksiklik veya fazlalık gibi herhangi bir olumsuzluk tespit edilmemiştir. Meyve eti sertliğinin artması ve meyve içeriğinde Se ve Si konsantrasyonlarının artması 
kaliteyi olumlu etkilemiştir. Selenyum ve Si'un hıyar ve diğer sebzelerin yetiştiriciliğinde yaprak gübresi olarak uygulama sıklığı ve dozları gelecekte yeni çalışmalarla detaylandırılmalıdır.

\section{Teşekkür}

Yazarlar, burada sunulan makaleyi ZF2013YL29 nolu proje ile finansal olarak destekleyen Çukurova Üniversitesi Bilimsel Araştırma Projeleri (BAP) koordinatörlüğüne teşekkürlerini sunmaktadır.

\section{Kaynaklar}

[1] Aktaş, M., "Bitkilerde Beslenme Bozuklukları ve Tanınmaları", (M. R. Karaman , A.R.Brohi editör). 3. Ulusal Gübre Kongresi: Tarım-Sanayi-Çevre : 11-13 Ekim 1.Cilt ,Nobel Basımevi , Ankara , s.1121-1126, 2004

[2] Hartikainen, H., "Biogeochemistry of selenium and its impact on food chain quality and human health”, J. Trace Elem. Med. Biol., 18, 309-318, 2005

[3] Girling, C.A., "Selenium in agriculture and the environment", Agriculture Ecosystem Environmental, , 37-65, 1984

[4] Combs, Gf. Jr., Luè J., “Mechanisms of selenium anticarcinogenesis”, 2001

[5] Hawkesford, M.J., Zhao, F.J., "Strategies for increasing the selenium content of wheat”, Journal of Cereal Science, 46 (3), 282-292, 2007

[6] Sumner, E.M., Handbook of soil science.CRC Press,Boca Raton,London,New York,Wasngton Dc.sustainable rice production. Adv. Agron. Academic Press, San Diego, CA, USA, 2001

[7] Epstein,E, “Silicon. Annv. Rev.”, Plant Physiol Plant Mol. Biology, 50, 641-644, 1999

[8] Meunier, J., "The role of plants in the transfer of silicon from the plant surface into the cytosol" , Geoscience, 335, 1199-1206, 2003

[9] Miyake,Y., Takahashi,E., "Silicon deficiency of tomato plant”, Soil Science Plant Nutrition, 24, 175-189, 1978

[10] Miyake,Y., Takahashi,E., "Effect of silicon on the growth of solution cultured cucumber plant" Plant Nutriton, 29, 71-83, 1983a

[11] Miyake,Y., Takahashi,E., "Effect of silicon on the growth of cucumber plant in soil culture". Soil Sci Plant Nutrition, 29, 463-471,1983b

[12] Miyake,Y., Takahashi,E., "Effect of silicon on the growth and of soybean plants in a solution culture”, Soil Sci Plant Nutrition, 31, 625-636, 1985

[13] Aranda, M.R.R., Oliva, J., Cuartero, J., "Silicon alleviates the deleterious salt effect on tomato plant growth by improving plant water status”, Journal of Plant Physiology, 5, 10, 2005

[14] Gong,H., Chen,G., Chen, G., Wang,S., Zhang, C., "Silicon alleviastes oxidatives damage of wheat plants in pots under drought”, Plant Science,169,313-321, 2005

[15] Casey, W.H., Kinrade, S.D., Knight, C.T.G., Rains, D.W., Epstein, E., “Aqueous silicate complexes in wheat Triticum aestivum L”, Plant Cell Environmental, 51-54, 2003 
[16] Ma. J.F., Goto, S., Tamai, K., Ichi, M., "Role of root hairs and lateral roots in silicon uptake by rice”, Plant Physiology, 127, 1773-1780, 2001

[17] Sripanyakorn, S., Raviin, J., Thompson, R.P.H., Powell, J.J., “Dietary silicon and bone health”, Nutrition Bulletin, 30 (3), 222-230, 2005

[18] Jones Junior, J.B. 1972. "Plant tissue analysis for micronutrients”. Editors: Mortvedt, J.J., Giordano, P.M., Lindsay, W.L. Micronutrients in agriculture. Madison: Soil Science Society of America, 319-346.

[19] Jones, J.B. Jr., B. Wolf, H.A. Mills, Plant Analysis Handbook. Micro Macro Publishing, Inc., 1991

[20] Kacar, B., İnal, A., Bitki Analizleri. Silisyum Belirlenmesi. Nobel Yayınları,782-783, 2008.

[21] Avcu, S., Akhoundnejad, Y, Daşgan H.Y., "Domateste tuz stresi üzerine selenyum ve silikon uygulamalarının etkileri”, Tarım Bilimleri Dergisi, 6 (1), 183-188, 2013

[22] Djanaguiraman M., Devi D.D, Shanker A.K., Sheeba J.A., Bangarusamy U. , "Impact of selenium spray on monocarpic senescence of soybean (Glycine Max L.)”, Food Agriculture \& Environment, 2 (2), 44-47, 2004

[23] Hu, H., Hu, C., Jie, X., Liu, S., Guo, X., Hua, D., Ma, C., Lu, J., Liu, H., “ Effects of selenium on herbage yield, selenium nutrition and quality of alfalfa”, Journal of Food, Agriculture \& Environment, 8 (2), 792 - 795, 2010

[24] Zhang, C., Moutinho-Pereira, J.M., Correia, C., Coutinho, J., Gonçalves, A., Guedes, GomesLaranjo, J., "Foliar application of Sili-K® increases chestnut (Castanea spp.) growth and photosynthesis, simultaneously increasing susceptibility to water deficit”, Plant Soil, 1385, 2012

[25] Bergmann, W., “Nutritional disordes of plants. development, visual and analytical diagnosis”, s.350, 1992

[26] Weise, H., Nikolic, M., Römheld, V., “Silicon in plant nutrition”, The Apoplast of Higher Plants: Compartment of Storage,Transport and Reactions, 33-47. B. Sattelmacher and W.J. Horst (eds.), Springer boks, 2007 